\title{
"PERAK" (PERANTI PEMURNI AIR KERUH) UNTUK MENGATASI KEKURANGAN AIR BERSIH DI DESA SENGGIGI
}

\section{Candra Dwipayana Hamdin ${ }^{1 *}$, Handa Muliasari ${ }^{1}$, Retno Zahara ${ }^{2}$, Mujiburrohman ${ }^{3}$, Devy Shandra Purwati ${ }^{4}$, Romi Juniawan ${ }^{5}$, Baiq Ressa Puspita Rizma ${ }^{1}$}

\author{
${ }^{1}$ Program Studi Farmasi, Fakultas Kedokteran, Universitas Mataram, Mataram, Indonesia \\ ${ }^{2}$ Program Studi D3 Akutansi, Fakultas Ekonomi dan Bisnis, Universitas Mataram, Mataram, Indonesia \\ ${ }^{3}$ Program Studi Fisika, Fakultas Matematika dan Ilmu Pengetahuan Alam, Universitas Mataram, Mataram, \\ Indonesia \\ ${ }^{4}$ Program Studi Ilmu Hukum, Fakultas Hukum, Universitas Mataram, Mataram, Indonesia \\ ${ }^{5}$ Program Studi Ilmu Komunikasi, Universitas Mataram, Mataram, Indonesia \\ *Penulis Korespodensi : candradwipayana@unram.ac.id
}

\begin{abstract}
Abstrak
Desa Senggigi merupakan salah satu daerah yang kekurangan pasokan air bersih, khususnya di Dusun Senggigi RT 04.Kondisi ini sangat memprihatinkan, sebab ketika musim kemarau tiba sangat sulit untuk memperoleh air bersih.Adapun air PDAM maupun air sungai sangatlah keruh sehingga tidak layak untuk digunakan.Oleh karena itu,dibutuhkan sebuah solusi terkait pengelolaan air keruh menjadi air bersih, yaitu PERAK (Peranti Pemurni Air Keruh).Tujuan dibuatkan program ini adalah terciptanya suatu alat pemurni air keruh (PERAK),terbentuk masyarakat yang terampil dalam mengelola air keruh menjadi air bersih, dan terbentuknya KelompokSwadaya Masyarakat di Dusun Senggigi. Metode yang digunakan dalam program ini adalah sosialisasi dan pelatihan pembuatan PERAK. Adapun hasil yang didapatkan pada pelaksanaan program ini adalah PERAK telah dapat menghasilkan air bersih yang dapat digunakan untuk keperluan kehidupan sehari-hari.Selain itu warga Dusun Seggigi juga telah mampu membuat PERAK dan telah dibentuknya Kelompok Swadaya Masyarakat yang bertugas memonitoring pelaksanaan program sehingga tercipta kemandirian dalam pelaksanaan program tersebut.Dengan demikian PERAK telah berhasil menjadi solusi bagi permasalahan kekurangan air bersih bagi Dusun Senggigi.
\end{abstract}

Kata kunci: Air Bersih; Air Keruh; Pemurni Air; PERAK; Senggigi.

\begin{abstract}
Senggigi Village is one of the areas that lack of clean water supply, especially in Dusun Senggigi RT 04. This condition is very concerning, because when the dry season comes, it is very difficult to obtain clean water. The PDAM water or river water is very muddy so it is not feasible to use. Therefore, it takes a solution related to the management of turbid water into clean water, which is PERAK (Refrigerant Water Purifier). The purpose of this PERAK program is to create a turbid water purification tool (PERAK), to form a skilled community in managing turbid water into clean water, and forming Self-Help Groups in Senggigi Village. The methods used in this program are socialization and training on making PERAK. As for the results obtained in the implementation of this program is PERAK has been able to produce clean water that can be used for the purposes of everyday life. In addition, residents of Dusun Senggigi has also been able to make PERAK and has formed a Self-Help Group which is tasked to monitor the implementation of the program so as to create independence in the implementation of the program. Thus PERAK has successfully become the solution for the problem of water shortage for Dusun Senggigi.
\end{abstract}

Keywords: Clean Wate; Cloudy Water; Water Purifier; PERAK; Senggigi. 


\section{PENDAHULUAN}

Sumber daya air merupakan bagian dari kekayaan alam yang dikelola secara menyeluruh, terpadu dan berwawasan lingkungan hidup dengan tujuan mewujudkan kebermanfaatan yang berkelanjutan yang diperuntukkan sebesar-besarnya bagi kemakmuran rakyat (UU No. 7 tahun 2004 tentang Sumberdaya Air, Pasal 3). Air merupakan kebutuhan dasar bagi manusia karena diperlukan antara lain untuk kebutuhan rumah tangga, industri, pertanian dan meningkatkan derajat kesehatan masyarakat (Boekoesoe, 2010). Akibat perkembangan penduduk yang pesat menimbulkan dampak meningkatnya kebutuhan air bersih (Herlambang \& Said, 2011).

Air bersih adalah salah satu kebutuhan dasar manusia yang seharusnya dapat dinikmati oleh seluruh masyarakat tanpa terkecuali (Kristianto, dkk., 2017). Ketersediaan air yang mudah dijangkau dan berkelanjutan berpengaruh terhadap kesehatan masyarakat, produktivitas, ekonomi dan kualitas kehidupan masyarakat secara keseluruhan (Susanto, dkk., 2014). Masyarakat dikatakan memiliki akses terhadap air bersih yaitu bila memenuhi syarat yaitu : (1) ketersediaan air dalam jumlah yang cukup untuk memenuhi kebutuhan sehari-hari, (2) kualitas air yang memenuhi baku mutu yang ditetapkan oleh Peraturan Menteri Kesehatan, dan (3) kontinuitas artinya air selalu tersedia ketika diperlukan (Azhar dkk., 2014). Berdasarkan ketentuan yang ada dalam Peraturan Menteri Kesehatan (Permenkes) No. 416/Menkes/PER/IX/1990, persyaratan air bersih meliputi kualitas fisik, kimia, bilogis, dan radiologi sehingga tidak menimbulkan efek samping apabila dikonsumsi. Ketersediaan air yang mudah dijangkau dan berkelanjutan berpengaruh terhadap kesehatan masyarakat, produktivitas ekonomi dan kualitas kehidupan masyarakat secara keseluruhan.

Pulau Lombok merupakan salah satu pulau di Indonesia yang mendapatkan dampak kekeringan akibat kurangnya pasokan air bersih. Terdapat sekitar 318 desa pada 71 kecamatan dilanda kekeringan dengan jumlah warga yang terdampak sebanyak $127.940 \mathrm{KK}$ atau 640.048 jiwa. Rincian daerah yang terdampak kekeringan di sembilan kabupaten/kota di wilayah NTB diantaranya 18 desa di Kabupaten Lombok Utara dan 25 Desa di Kabupaten Lombok Barat (Suara NTB, 2018). Salah satu daerah yang mengalami kekurangan pasokan air bersih adalah desa Senggigi, khususnya di Dusun Senggigi RT 04. Kondisi Dusun Senggigi RT 04 hingga saat ini masih memprihatinkan terkait masalah ketersediaan air. Ketika musim kemarau tiba, air bersih sangat sulit untuk diperoleh. Ketika musim penghujan, masyarakat hanya mengandalkan air yang bersumber dari hutan di sekitar desa yang airnya keruh untuk memenuhi kebutuhan sehari-hari. Masyarakat di daerah tersebut sudah membuat bak penampungan air di lokasi mata air yang berada di sekitar hutan. Air yang tertampung di bak penampungan dialirkan ke rumahrumah penduduk menggunakan pipa. Akan tetapi, sistem distribusi tersebut sudah tidak ada. Hal ini disebabkan oleh beberapa hal seperti sarana yang digunakan tidak berfungsi lagi, masalah pengelolaan yang kurang baik, serta jaringan pipa yang terbatas. Oleh karena itu, warga harus mengambil air langsung dari mata air yaitu hutan yang jarak tempuhnya cukup jauh.

Alternatif lain untuk memenuhi kebutuhan air adalah menggunakan jaringan pipa PDAM. Akan tetapi, kualitas air nya tidak terjamin bagus. Beberapa dirigen pengangkut air dan kualitas air PDAM dapat dilihat pada Gambar 1 (a) dan (b) secara berurutan. Disamping itu, distribusi air hanya pada beberapa rumah penduduk saja dan kuantitasnya sedikit, sehingga penduduk di sana rela berjaga tengah malam untuk mendapatkan air. Berikut pendapat dari Bapak Hairul ketua RT. 04 Desa Senggigi (Hasil observasi dan Wawancara Personal, 23 April 2018).

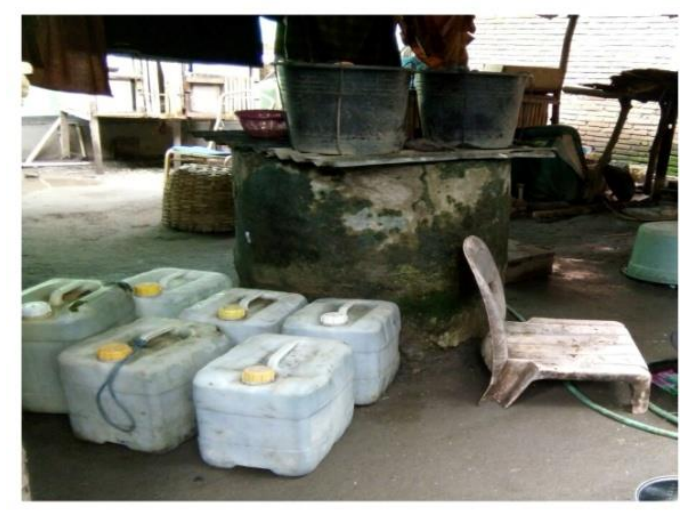

(a)

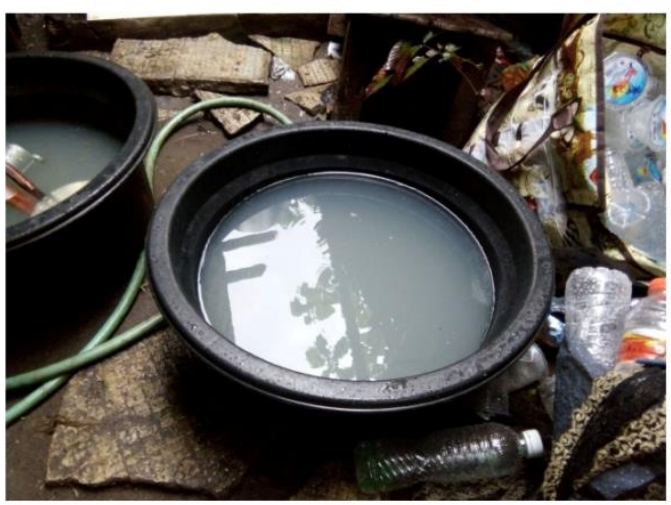

(b)

Gambar 1. Kondisi air di Dusun Senggigi RT 04 (a) Kumpulan jerigen, (b) Air keruh dalam ember.

Berdasarkan pemaparan di atas, solusi yang dilakukan untuk mengatasi ketersediaan air bersih di Desa Senggigi khususnya RT 04 Dusun Senggigi yakni menggunakan PERAK (Peranti Pemurni Air Keruh). PERAK merupakan alat yang digunakan untuk memfiltrasi air keruh menjadi air bersih dengan mengoptimalkan karakteristik air tanpa merusak alam sekitarnya. Selain itu, proses pembuatan yang sederhana dan mudah dikembangkan serta peralatan yang digunakan mudah didapatkan mampu mengatasi masalah kekurangan air bersih di RT 04 Dusun 
Senggigi, Desa Senggigi. Pelaksana juga melakukan pelatihan PERAK untuk mengembangkan keterampilan masyarakat dalam mengatasi permasalahan yang ada.

Adapun tujuan yang ingin dicapai dalam kegiatan ini adalah (1) Terciptanya suatu alat pemurni air keruh (PERAK) yang mampu memfiltrasi air keruh menjadi air bersih untuk mengatasi permasalahan air bersih di RT 04 Dusun Senggigi, Desa Senggigi; (2) Terbentuk masyarakat yang terampil dalam mengelola air keruh menjadi air bersih; dan (3) Terbentuknya Kelompok Swadaya Masyarakat (KSM) di RT 04 Dusun Senggigi yang bertanggung jawab mengembangkan PERAK untuk mengatasi permasalahan air bersih.

\section{BAHAN DAN METODE}

Pelaksanaan kegiatan pengabdian menggunakan pendekatan studi kasus. Data yang dikumpulkan bersifat bersumber dari observasi dan wawancara, meliputi data fisik wilayah, data sosial-ekonomi, dan data kondisi pengelolaan sarana air bersih, termasuk data kualitas air yang digunakan.

Metode pelaksanaan dalam program PERAK meliputi 7 tahapan yakni observasi daerah sasaran, izin pelaksanaan program, sosialisasi program, pelatihan pembuatan PERAK, pembentukan Kelompok Swadaya Masyarakat (KSM) sebagai mitra program, monitoring program serta yang terakhir adalah evaluasi program. Dalam pelatihan Pembuatan PERAK digunakan metode simulasi pembuatan PERAK dengan bimbingan dari tim PERAK dan beberapa volunteer. Bahan-bahan yang dibutuhkan untuk membuat PERAK yaitu jerigen, kerikil, ijuk, kapas, pasir halus, kain, arang, dan alkohol.

\section{HASIL DAN PEMBAHASAN}

Kegiatan pertama dalam program pengabdian kepada masyarakat ini adalah observasi. Observasi daerah sasaran dilakukan di RT 04 Dusun Senggigi, Desa Senggigi. Observasi dilakukan selama $3 \mathrm{x}$ dalam pelaksanaan program. Observasi pertama dilakukan untuk mengetahui keadaan lingkungan geografis Dusun Senggigi, Desa Senggigi terutama berkaitan dengan sumber air, tempat penampungan air, saluran pipa, serta kondisi air pada saat musim hujan. Observasi kedua dilakukan untuk mencari tahu sejauh mana permasalahan yang terjadi di masyarakat melalui wawancara langsung kepada masyarakat Dusun Senggigi, Desa Senggigi. Observasi ketiga untuk memastikan terlaksananya program PERAK. Hasil observasi wilayah dan kondisi air menunjukkan ketersediaan air bersih terbatas dan kualitas air yang buruk di wilayah sasaran sebagaimana ditunjukkan pada Gambar 1 dan 2.

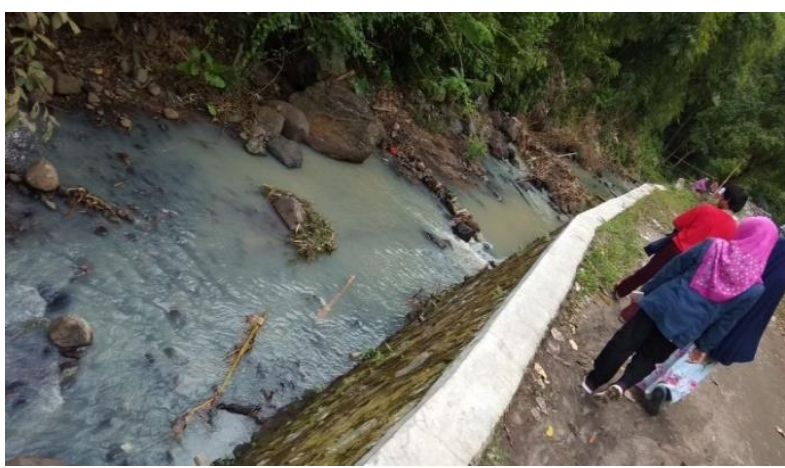

Gambar 2. Observasi Kondisi daerah sasaran.

Setelah melakukan observasi daerah sasaran, tahapan selanjutnya adalah pengajuan permohonan izin dan kerjasama sebagai mitra program PERAK di RT 04 Dusun Senggigi, Desa Senggigi. Permohonan izin dan kerjasama dalam program ini melalui RT setempat yakni Bapak Hairul dan masyarakat setempat.

Tahap ketiga yakni kegiatan sosialisasi yang dilakukan untuk memberikan pemahaman kepada masyarakat akan pentingnya air bersih bagi kehidupan serta mengajak masyarakat untuk peduli dengan masalah kurangnya air bersih. Penyampaian materi dalam sosialisasi ini dilakukan dengan cara pendekatan langsung kepada masyarakat, melakukan beberapa permainan yang dapat menyadarkan masyarakat akan pentingnya air bersih, serta melakukan sesi tanya jawab dan pembagian doorprize setelah penyampaian materi selesai.

Kegiatan tersebut diikuti oleh 83 warga Dusun Senggigi, Desa Senggigi. Kegiatan dimulai dari pembukaan seperti sambutan dari Kepala Dusun, Ketua Kelompok PKM, tilawah, dan do'a. Setelah itu diadakannya Penyuluhan Air Bersih sebagai edukasi masyarakat akan pentingnya air bersih. Dilanjutkan dengan sosialiasi program PERAK. Dalam pengenalan program ini, sambutan warga sangat baik. Hal ini diketahui dari respon-respon warga saat sesi tanya jawab.

Pelatihan Pembuatan PERAK dilakukan setelah diadakannya sosialiasi program PERAK. Konsepnya adalah pemateri menjelaskan teknik pembuatan PERAK, dimulai dari pengenalan bahan-bahan, tata cara pembuatan, dan demo pembuatan PERAK. Diselasela penyampaian materi diadakan beberapa tanya jawab terkait pembuatan PERAK. 


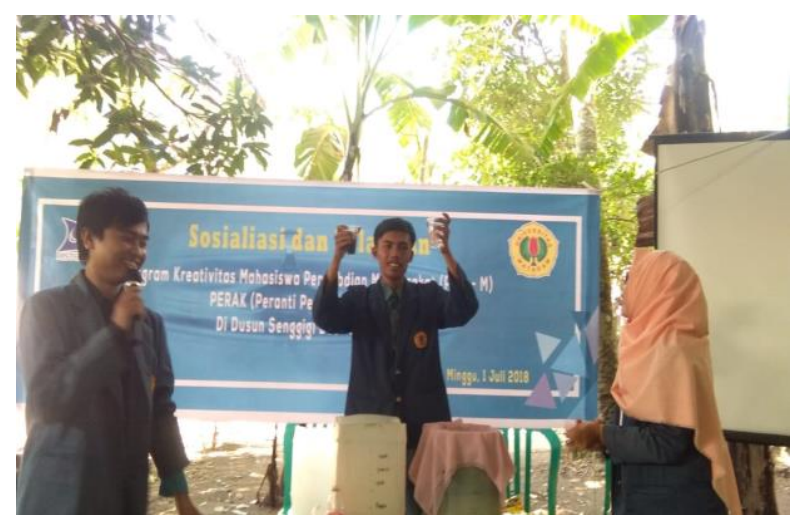

Gambar 3. Sosialisasi Program PERAK.

\subsection{Pelatihan pembuatan alat PERAK}

Alat PERAK berhasil dibuat sesuai dengan model rancangannya pada Gambar 4. Tinggi dirigen sekitar 45 cm yang dibagi menjadi 7 bagian seperti pada gambar. Bagian-bagian tersebut dibuat dengan urutan dari atas ke bawah adalah kain, ijuk, pasir halus, ijuk, pasir halus, arang, kerikil, dan kapas. Karbon berfungsi sebagai sarana proses filterisasi dengan tujuan mengadakan penyaringan untuk jenis-jenis material yang terdapat dalam air, seperti bau, kekeruhan, serta warna-warna yang mungkin timbul pada air baku dan menyaring kotoran dengan ukuran antara $1 \mathrm{~s} / \mathrm{d} 2 \mathrm{~mm}$ (Wiyono, dkk., 2017).

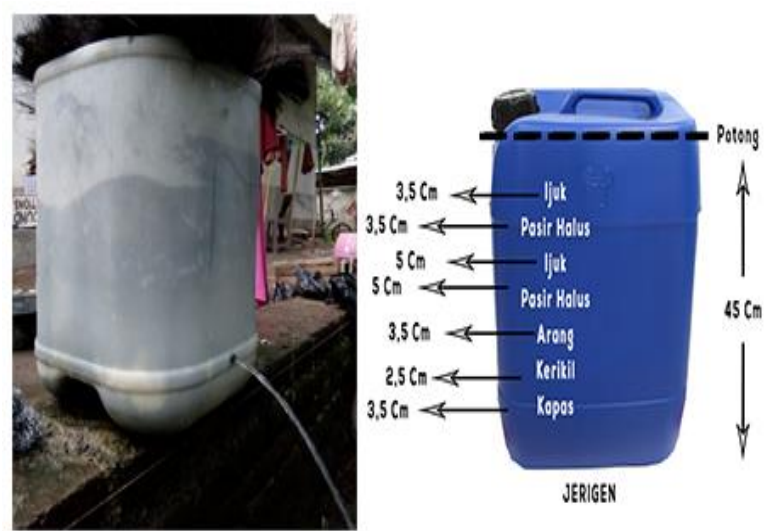

Gambar 4. Alat PERAK (Peranti Pemurni Air Keruh).

Adapun tahap-tahap pembuatan PERAK adalah sebagai berikut; a) Potong bagian kepala jerigen kemudian sterilisasikan menggunakan alkohol. b) Lubangi bagian samping bawah jerigen. c) Isi jerigen dengan bahanbahan yang sudah disiapkan untuk filtrasi air dengan urutan seperti pada Gambar 4. d) Setelah diisi dengan semua media penyaring, masukkan air keruh ke dalam jerigen. e) Jika air yang keluar dari penyaringan pertama tidak terlalu jernih, ulangi lagi langkah prosesnya.

Dari semua komponen bahan pada dirigen, dapat diketahui bahwa semua bahan filter merupakan bahan adsorben yang alami dan penyaring yang baik sehingga dapat menghasilkan kualitas air yang jernih dan sehat (Handarsari, dkk., 2017). Selain itu, bahan-bahannya mudah didapatkan dan pembuatannya pun sangatlah mudah. Pada saat pelatihan pembuatan PERAK, respon dari pihak warga sangatlah baik dan mendukung diadakanya program yang diusulkan. Selain itu, program tersebut diharapkan dapat dirasakan manfaatnya oleh masyarakat sekitar.

\subsection{Pembentukan KSM}

Tahap kelima yakni pembentukan Kelompok Swadaya Masyarakat (KSM) sebagai mitra program setelah pelatihan PERAK. Kelompok ini merupakan mitra yang bertanggung jawab terhadap pengembangan PERAK dan ketersediaan air bersih di RT 04 Dusun Senggigi, Desa Senggigi. KSM yang terbentuk beranggotakan 30 warga yang bersedia, terdiri dari masyarakat, para pemuda desa, tokoh masyarakat dan ketua RT 04 Dusun Senggigi, Desa Senggigi. Pembentukan KSM ini dilakukan guna memantau perkembangan dan ketersediaan air bersih di Dusun Senggigi, Desa Senggigi.

KSM memiliki struktur organisai berupa Ketua, Sekretaris, Bidang Kontroling dan Bidang Penyedia. Adapun deskripsi kerja dari ketua adalah sebagai penanggungjawab keberlangsungan dari program PERAK serta keaktifan anggota kelompok. Sekretaris sebagai notulen dan wakil bagi ketua KSM jika berhalangan hadir. Bidang Kontroling bertugas untuk mengontrol berjalannya pembuatan PERAK. Bidang Penyedia bertugas untuk menyiapkan bahan-bahan pembuatan PERAK.

Kegiatan monitoring dilakukan melalui media sosial instagram untuk melihat kinerja para kader program PERAK di RT 04 Dusun Senggigi, Desa Senggigi. Pemantauan berjalannya program dilihat dari hasil postingan para kader PERAK dan kunjungan ke Dusun Senggigi, Desa Senggigi setiap satu bulan sekali. Tahap terakhir yakni evaluasi dilakukan pada akhir program kegiatan tersebut guna mengukur sejauh mana pencapaian dari program tersebut dan hasil akhir program. Hasil akhir ini menjadi bahan evaluasi untuk program selanjutnya.

\section{KESIMPULAN}

Masyarakat Dusun Senggigi memberikan respon yang positif dan berpartisipasi secara aktif dalam pelaksanaan program pembuatan PERAK (Peranti Pemurni Air Keruh). Dengan diadakannya sosialisasi program dan pelatihan pembuatan PERAK, warga telah dapat dengan terampil membuat sendiri alat pengelola air keruh menjadi air bersih. Dengan demikian, masyarakat di daerah tersebut telah mendapatkan air bersih yang dapat digunakan untuk keperluan sehari-hari. Selain itu, KSM yang berhasil dibentuk membantu dalam hal pemantauan terhadap pengembangan PERAK dan ketersediaan air bersih di RT 04 Dusun Senggigi, Desa Senggigi. Keberlanjutan program pembuatan PERAK dan pengembangannya kepada masyarakat yang lebih luas sangat diharapkan melalui peran KSM beserta aparat desa setempat. 


\section{UCAPAN TERIMA KASIH}

Ucapan terima kasih disampaikan untuk ketua RT 04 Dusun Senggigi beserta warga.

\section{DAFTAR PUSTAKA}

Azhar, K., Dharmayanti, I., \& Anwar, A. 2014. The Influence of Drinking Water Access on the Occurrence of Water-borne Diseases (Diarrhea and Typhoid). Buletin Penelitian Sistem Kesehatan, 17(2), 107-114.

Boekoesoe, L. 2011. Tingkat Kualitas Bakteriologis Air Bersih di Desa Sosial Kecamatan Paguyutan Kabupaten Boalemo. Jurnal INOVASI, 7 (4), 240-251.

Hairul, 2018. Wawancara tentang "Keadaan Desa Sengggigi" di rumah Bapak Hairul, Dusun Senggigi Desa Senggigi.

Handarsari, E., F. F. Hidayah, Y. K. Sya'di. 2017. Deseminasi: Pembuatan Air Bersih Dengan Memanfaatkan Air Hujan Melalui Penyaring Pipa Bersusun Berbasis Adsorben Alami. Prosiding Seminar Nasional Publikasi HasilHasil Penelitian dan Pengabdian Masyarakat "Implementasi Penelitian dan Pengabdian MasyarakatUntuk Peningkatan Kekayaan Intelektual" Universitas Muhammadiyah Semarang, 30 September 2017.

Herlambang, A., \& Said, N. I. 2011. Aplikasi Teknologi Pengolahan Air Sederhana untuk Masyarakat Pedesaan. Jurnal Air Indonesia, 1(2), 113-122.

Kristianto, H., Katherine, J.N. M. Soetedjo, F. Pratiwi, C. W. Handriono, V. J. Guntoro, R. J. Farand, B. Y. Suhendar , Y. Mulyana. 2017. Penyediaan Air Bersih Masyarakat Sekitar Masjid Al-Ikhlas Desa Cukanggenteng, Ciwidey dengan Penyaringan Air Sederhana. JPKM, $\quad 3$ (1), 39-49. DOI: http://doi.org/10.22146/jpkm.28148

Peraturan Menteri Kesehatan. No. 416 Tahun 1990. Tentang :Syarat-syarat Dan Pengawasan Kualitas Air.

SuaraNTB,2018.https://www.suarantb.com/ntb/2017/0 9/245274/NTB.Masih.Butuh.Air.Bersih.153.J uta.Liter/. diakses pada tanggal 27 Oktober 2019 pukul 18.10 WITA.

Susanto, D., T.U. Kalsum., Y. Suzantri. 2014. Alat Penyaringan Air Kotor Menjadi Air Bersih Menggunakan Mikrokontroller Atmega 32. Jurnal Media Infotama 10(2), 142-150.

Undang-undang Republik Indonesia No 7 tahun 2004 tentang sumber daya air pasal 3 .

Wiyono, N., A. Faturrahman., A. Syauqiah. 2017. Sistem Pengolahan Air Minum Sederhana (Portable Water Treatment). Jurnal Konversi, $6(1), 27-35$. 